\title{
TYPES OF GOVERNMENT DEFICIT IN RESPECT OF FISCAL DECISION-MAKING
}

\author{
Agnieszka Przybylska-Mazur \\ University of Economics in Katowice, Katowice, Poland \\ e-mail: agnieszka.przybylska-mazur@ue.katowice.pl \\ (C) 2018 Agnieszka Przybylska-Mazur \\ This is an open access article distributed under the Creative Commons Attribution-NonCommercial- \\ -NoDerivs license (http://creativecommons.org/licenses/by-nc-nd/3.0/) \\ DOI: 10.15611/fins.2018.2.05 \\ JEL Classification: B62, E10, E32, C54

\begin{abstract}
Fiscal policy includes the government decisions on the size of taxes that affect the size of the government deficit. There are different types of government deficit. The aim of the analyses is to examine the relation between the type of deficit and the optimal level of tax rate. In this article we verify the hypothesis that the type of deficit considered affects the tax rate. For the hypothesis verification, we use the feedback rules that are the solution of the quadratic-linear problem.
\end{abstract}

Keywords: deficit, tax rate, feedback rule, quadratic-linear problem.

\section{Introduction}

Monetary and fiscal policies have a fundamental importance in the realization of macroeconomic policy. Tax policy is the basic component of fiscal policy. Decisions regarding the values of microeconomic instruments of fiscal policy, which include taxes, have an impact on macroeconomic fiscal policy instruments, such as government (budget) revenues and government (budget) balance, government (budget) deficit or government (budget) surplus. Decisions based on rules are one of the ways of decision-making. When we make a fiscal policy decision based on fiscal rules, the prudence of fiscal policy and objectivity in the implementation of fiscal policy are strengthened. Fiscal rules have a significant impact on the economy. In addition, there are many benefits for the economy resulting from the application of fiscal rules. The creation of favorable conditions to increase the potential GDP growth rate is one of the benefits. However, it is not sufficient to introduce rules in order to fulfill their corrective function. Effective fiscal rules should refer to the entire public finance sector. These rules should be relatively simple and flexible. If a fiscal impulse is necessary to stimulate the economic situation, the possibility of a government deficit should be allowed. However, the fiscal impulse cannot lead to the permanent growth of public debt and to the permanent growth of deficit. 
Since we have various types of deficit and we have different methodologies to calculate the deficit, this paper takes into account additional objectives such as price stabilization, GDP growth and deficit stability; we also analyze the impact of the type of deficit on the level of tax rates. The aim of this article is to examine the relation between the type of deficit and the optimal level of tax rate.

In the EU countries, data on the general government deficit are made in accordance with the methodology of the European System of National and Regional Accounts in the European Union (ESA 2010). The assumptions of the national accounts system are consistent with both the United Nations and European Union guidelines, including the specificity of the organizational and legal system in force in a given country.

Various types of deficit, as well as their relation with fiscal policy, are also discussed by many authors in different countries (see for example: [Boiciuc 2015; Camelia 2014; Fantacone et al. 2015; Okafor et al. 2017]).

In order to make the analysis we use the algorithm based on the control theory and based on the dynamic model. To achieve the assumed goals such as coordination of the fiscal and monetary policies, this model takes into account the feedback rules.

The application of these rules allows the economy to develop according to the desired path.

\section{Quadratic-linear problem}

Many problems in economics are modeled using dynamic models. These models can be the basis for the determination of the strategy, whose effect is to achieve the desired values of selected variables in the future, such as inflation, GDP and the level of deficit or public debt. We take into account the inflation rate and GDP because these variables are the main variable which have an impact on the economy. In addition, price stability and economic growth are the main goals of state macroeconomic policy. The fiscal rule which is the feedback rule can be determined as a solution of the quadratic-linear problem [Benigno, Woodford 2012; Ellison]. The quadratic-linear problem is as follows:

For each $t=0,1, \ldots, N-1$, we calculate the control vector $U_{t}$ for which the function defined by the formula [Kendrick 1982; Przybylska-Mazur 2016]:

$$
\begin{gathered}
J=\frac{1}{2}\left(X_{N}-X_{N}^{*}\right)^{T} \cdot V_{N} \cdot\left(X_{N}-X_{N}^{*}\right)+ \\
+\frac{1}{2} \sum_{t=0}^{N-1}\left(\left(X_{t}-X_{t}^{*}\right)^{T} \cdot V_{t} \cdot\left(X_{t}-X_{t}^{*}\right)+\left(U_{t}-U_{t}^{*}\right)^{T} \cdot S_{t} \cdot\left(U_{t}-U_{t}^{*}\right)\right) .
\end{gathered}
$$

reaches the minimum. In the applied quadratic-linear problem, the linear dynamic model is the limiting condition. This linear dynamic model can be written in the matrix form as follows [Kendrick, Amman 2011; Przybylska-Mazur 2016]: 


$$
X_{t+1}=A \cdot X_{t}+B \cdot U_{t} \text { for each } t=0,1, \ldots, N-1
$$

with the initial condition

$$
X_{0}=\tilde{X}_{0},
$$

where: $X_{t}-$ vector of state variables in the period $t, U_{t}-$ vector of control variables in the period $t, X_{t}^{*}$ - vector of desired values of state variables in the period $t$, $U_{t}^{*}$ - vector of desired values of control variables in the period $t, A$-accompanying matrix, $B$ - multiplier vector of impact of interest rates, $\tilde{X}_{0}-$ determined initial value of the state vector, the state vector in period $t=0, V_{t}$ - positively determined symmetric matrix of deviations of state variables from the desired values of state variables.

If the matrix $V_{t}$ is a diagonal matrix, the elements on the main diagonal are the weights assigned to deviations of the vector of the state variables from the vector of the desired values of the state variables.

$S_{t}$ - positively determined symmetric matrix of deviations of control variables from the desired values of control variables.

If the matrix $S_{t}$ is a diagonal matrix, the elements on the main diagonal are the weights assigned to deviations of the vector of the control variables from the vector of the desired values of the control variables.

In this paper we take the following state variables: inflation rate $\pi_{t}$, GDP growth rate $Y_{t}$ and deficit $D_{t}$, and more precisely the deficit to GDP ratio, therefore $X_{t}=\left[\begin{array}{c}\pi_{t} \\ Y_{t} \\ D_{t}\end{array}\right]$, while the control variables are: interest rate $i_{t}$ and tax rates: the basic PIT rate $\tau_{t}$ and the basic VAT rate $v_{t}$, i.e. $U_{t}=\left[\begin{array}{c}i_{t} \\ \tau_{t} \\ v_{t}\end{array}\right]$. The vectors of the desired values of state and control variables are the following: $X_{t}^{*}=\left[\begin{array}{c}\pi_{t}^{*} \\ Y_{t}^{*} \\ D_{t}^{*}\end{array}\right]$ and $U_{t}^{*}=\left[\begin{array}{c}i_{t}^{*} \\ \tau_{t}^{*} \\ v_{t}^{*}\end{array}\right]$, where: $\pi_{t}^{*}$ is the inflation target, $Y_{t}^{*}-$ the potential GDP, $D_{t}^{*}-$ the desired value of deficit, $i_{t}^{*}-$ the natural interest rate, $\tau_{t}^{*}, v_{t}^{*}$ - the desired values of tax rates. Since the linear trend is the better model for the tax rates, we take the values calculated from the linear trends as the desired values of tax rates. 
In addition we assume: $V_{t}=\left[\begin{array}{ccc}\lambda_{\pi t} & 0 & 0 \\ 0 & \lambda_{Y t} & 0 \\ 0 & 0 & \lambda_{D t}\end{array}\right], S_{t}=\left[\begin{array}{ccc}\lambda_{i t} & 0 & 0 \\ 0 & \lambda_{\tau t} & 0 \\ 0 & 0 & \lambda_{v t}\end{array}\right]$.

Thus the optimal linear feedback rule which is the solution to the problem (1)-(3) is calculated from the formulas [Kendrick, Amman 2011; Przybylska-Mazur 2016]:

$$
U_{t}=G_{t} \cdot X_{t}+g_{t} \text { for each } t=0,1, \ldots, N-1,
$$

where: $G_{t}$-the feedback gain matrix in the period $t, g_{t}-$ vector of feedback parameters in the period $t$, that are calculated from the following formulas:

$$
\begin{gathered}
G_{t}=-\left(B^{T} \cdot K_{t+1} \cdot B+S_{t}^{T}\right)^{-1} \cdot B^{T} \cdot K_{t+1} \cdot A, \\
g_{t}=-\left(B^{T} \cdot K_{t+1} \cdot B+S_{t}^{T}\right)^{-1} \cdot\left[B^{T} \cdot p_{t+1}-S_{t} \cdot U_{t}^{*}\right] .
\end{gathered}
$$

The matrix $K_{t}$ and the vector $p_{t}$ satisfy the Riccati equations [Ferrante, Ntogramatzidis 2013], defined as follows:

For each $t=1,2, \ldots, N-1$

$$
\begin{gathered}
K_{t}=V_{t}+A^{T} \cdot K_{t+1} \cdot A-A^{T} \cdot K_{t+1} \cdot B \cdot\left(B^{T} \cdot K_{t+1} \cdot B+S_{t}^{T}\right)^{-1} \cdot B^{T} \cdot K_{t+1} \cdot A, \\
p_{t}=A^{T} \cdot p_{t+1}-V_{t} \cdot X_{t}^{*}-A^{T} \cdot K_{t+1} \cdot B \cdot\left(B^{T} \cdot K_{t+1} \cdot B+S_{t}^{T}\right)^{-1} \cdot\left(B^{T} \cdot p_{t+1}-S_{t} \cdot U_{t}^{*}\right)
\end{gathered}
$$

while for $t=N$ :

$$
\begin{gathered}
K_{N}=V_{N}, \\
p_{N}=-V_{N} \cdot X_{N}^{*} .
\end{gathered}
$$

Therefore, taking into account the matrix form (4), the fiscal rules can be written in the following form:

$$
\begin{aligned}
& \tau_{t}=G_{21, t} \cdot \pi_{t}+G_{22, t} \cdot Y_{t}+G_{23, t} \cdot D_{t}+g_{2}, \\
& v_{t}=G_{31, t} \cdot \pi_{t}+G_{32, t} \cdot Y_{t}+G_{33, t} \cdot D_{t}+g_{3} .
\end{aligned}
$$

The fiscal rules present the dependence of the level of microeconomic fiscal policy instruments on the considered state variables: inflation rate, GDP growth rate and deficit. 
Since the values of different types of deficits are not equal, we study the impact of the type of deficit on decisions about tax rates, taking into account the achievement of price stability, the assumed GDP growth rate and the assumed level of deficit.

We should also note that factors not related to fiscal policy also affect the government deficit. The disturbances, called 'animal instincts' by Keynes, which are spontaneous changes in investors' pessimism and investors' optimism, affect the changes in investment demand and the changes in the deficit, on the assumption of constant state expenditure and constant tax rate.

\section{Deficit - types and methodology of calculation}

In this part of the article we discuss the different types of deficit used later in the context of the government deficit and we notice the divergences in the methodology of the calculation of deficit.

We distinguish three types of deficit:

- real deficit,

- structural deficit,

- cyclical deficit.

These types of deficit will be briefly discussed below.

The real deficit is calculated as the difference between government expenditures and government revenues in the given settlement period.

Calculating the structural deficit we assume that the government revenues and the government expenditures are realized when the production capacity of the economy is fully used. The structural deficit allows to determine what the condition of public finances would be if the economy is working with the full use of the production potential.

The structural deficit or, more generally, the structural balance, known also as the government balance of full employment or the government balance adjusted by the influence of fluctuations in the business cycle, is hypothetical but it can be used as an indicator of fiscal policy character, which presents the state of the budget in conditions of full employment and at the level of potential production.

This deficit can be calculated from the following formula:

$$
S_{t}^{*}=v_{t} \cdot Y_{t}^{*}-W_{t}-P_{t},
$$

where: $S_{t}^{*}$ - government balance in conditions of full employment, $v_{t}-$ tax rate, $Y_{t}^{*}-$ potential production, $W_{t}-$ government expenditures, $P_{t}-$ transfer payments (social security benefits and public debt interest).

The structural deficit is a hypothetical value. This deficit shows what would be the size of the government balance or the public finance sector balance in the absence of cyclical factors, when we assume that the actual production is equal to 
potential production. We often assume that the structural government deficit also includes the correction of one-off and extraordinary factors of a temporary nature, in addition to the correction of the cycle impact.

The cyclical deficit takes into account the influence of the business cycle phase on government expenditures and government revenues in conditions when the economy does not work with the full use of production factors. This deficit is usually the result of the use of automatic stabilizers.

As the variable determining the phase of the business cycle, in this article we consider the output gap $i_{Y_{t}}$ which we define as the potential GDP $Y_{t}^{P}$ to the real value of GDP $Y_{t}$ ratio, i.e.

$$
i_{Y_{t}}=\frac{Y_{t}^{P}}{Y_{t}} .
$$

If $i_{Y_{t}}>1$, we have a recession and the government expenditures are higher than the government revenues. If $i_{Y_{t}}<1$, we have a phase of economic boom, and the government revenues exceed the government expenditures.

We should note the problem of the assessment of the government balance and the problem of international comparisons of the deficit. We have a different methodology of calculation of the deficit because significant proportion of government revenues, government expenditures and government liabilities are performed outside the government budget. Hence the general government sector deficit is often used.

The different methods of calculation of the deficit are used by:

- International Monetary Fund - the Government Finance Statistics (GFS) method;

- European Union - the accrual method; this method defines a deficit as an increase in net borrowing, while a surplus as an increase in net lending;

- Poland - one of the methods in Poland is the method included in the Act of 27 August 2009 on Public Finances (Journal of Laws 2009, no 157 position 1240). Article 113 paragraph 1 says that: "The difference between government revenues and government expenditures is, respectively, the government surplus or the government deficit, with the exception of Article 118 paragraph 2" which states that: "The deficit of European funds or the surplus of European funds are not included in the government deficit or the government surplus, respectively." In addition, article 7 paragraph 2 states that: "The public revenues, the public expenditures and the general government surplus or the general government deficit should be determined after the elimination of financial flows between units of this sector." 


\section{Empirical analyses}

Taking into account the different types of deficit, we calculate the optimal tax rates on basis of the models that include, in addition to the inflation rate (annual data, the corresponding period of the previous year $=100$ ) (source: www.stat.gov.pl), and GDP growth (annual data) (source: www.stat.gov.pl):

1) real government deficit, which is calculated as the difference between government expenditures and government revenues in a given settlement period,

2) structural government deficit,

3) government deficit that takes into account the impact of the business cycle phase on government revenues and government expenditures in conditions when the economy does not work with the full use of production factors.

However, taking into account the different methodologies of the calculation of the deficit, we calculate the optimal tax rates based on the models which, in addition to the inflation rate and GDP growth, include: the government deficit (annual data) (source: www.stat.gov.pl) or the general government deficit (annual data) (source: http://ec.europa.eu/eurostat/data/database). In the considered models we take into account the relation of the appropriate deficit to GDP.

Since the achievement of such goals as price stability, economic growth and the desired level of the deficit is possible thanks to the coordination of monetary and fiscal policy, we take the following variables as the control variables: the reference rate (average annual values) and the tax rates: basic PIT and VAT rates (annual data), which are the decision variables.

For the analyses we take into account the data for Poland from 2004-2016.

We take the following desirable values of the state variables: the inflation target, the potential GDP calculated on the basis of the Hodrick-Prescot filter. We take the following desired level of deficit in all the models: the medium-term budgetary objective, which is different for the individual EU countries, while for Poland this objective corresponds to the structural deficit and this objective equals $1 \%$ of GDP.

However, the desired coordinate values of the control vector are: the natural interest rate determined on the basis of the H-P filter, as well as the desirable values of PIT and VAT rates calculated on the basis of the linear trend function.

In addition, assuming the equal importance of all the objectives and all the fiscal and monetary policy instruments, we take the fixed weights for each $t$, i.e.

$$
V_{t}=\left[\begin{array}{ccc}
\frac{1}{3} & 0 & 0 \\
0 & \frac{1}{3} & 0 \\
0 & 0 & \frac{1}{3}
\end{array}\right] \text { and for each } t S_{t}=\left[\begin{array}{ccc}
\frac{1}{3} & 0 & 0 \\
0 & \frac{1}{3} & 0 \\
0 & 0 & \frac{1}{3}
\end{array}\right] .
$$

The following figures present the individual types of deficit and deficit calculated on the basis of the described different methodologies. 


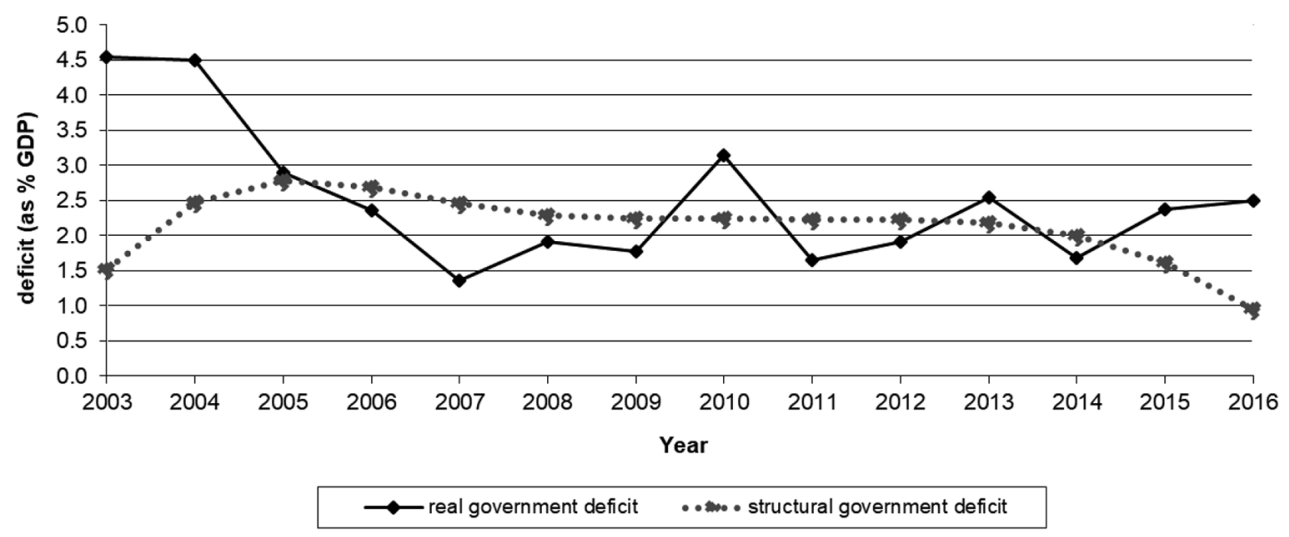

Fig. 1. The real government deficit and the structural government deficit (as \% GDP)

Source: own calculation.

Thus we can observe significant differences between the real deficit and the structural deficit representing the government deficit in conditions of full employment and when the production is equal to the potential production. This structural deficit is also the government deficit corrected by the impact of fluctuations in the business cycle.

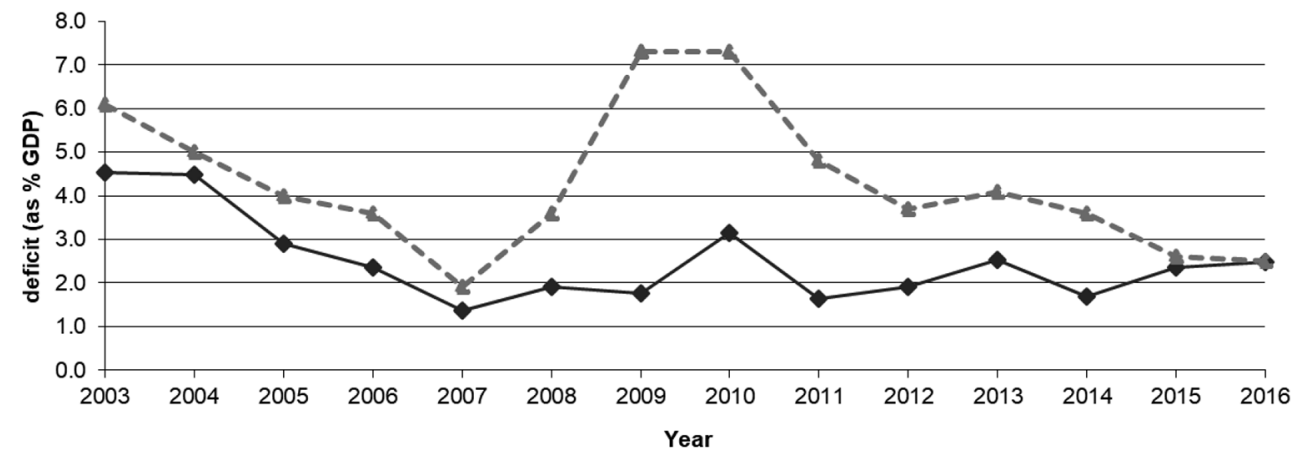

$$
\longrightarrow \text { government deficit } \quad \text { 늘 }- \text { general government deficit }
$$

Fig. 2. The government deficit and the general government deficit (as \% GDP)

Source: own calculation.

First of all we can observe the differences between the government deficit and the general government deficit. We calculate the optimal values of PIT and VAT tax rates based on the obtained values of deficits. These optimal tax rates are summarized in the tables below. 
Table 1. The optimal values of PIT rates calculated on the basis of the model with the real government deficit and the structural government deficit as well as the real values of PIT rate

\begin{tabular}{|c|c|c|c|}
\hline Year & $\begin{array}{c}\text { The optimal PIT rate calculated } \\
\text { on the basis of model } \\
\text { with the real government deficit }\end{array}$ & $\begin{array}{c}\text { The optimal PIT rate calculated } \\
\text { on the basis of a model with the } \\
\text { structural government deficit }\end{array}$ & $\begin{array}{c}\text { Real values } \\
\text { of PIT rate }\end{array}$ \\
\hline 2003 & 17.79 & 18.13 & 19 \\
\hline 2004 & 18.34 & 18.31 & 19 \\
\hline 2005 & 18.70 & 18.85 & 19 \\
\hline 2006 & 18.91 & 18.92 & 19 \\
\hline 2007 & 18.99 & 18.59 & 19 \\
\hline 2008 & 18.77 & 18.41 & 19 \\
\hline 2009 & 18.62 & 18.45 & 18 \\
\hline 2010 & 18.41 & 18.42 & 18 \\
\hline 2011 & 18.48 & 18.06 & 18 \\
\hline 2012 & 18.26 & 18.18 & 18 \\
\hline 2013 & 18.01 & 18.39 & 18 \\
\hline 2014 & 17.82 & 18.21 & 18 \\
\hline 2015 & 17.10 & 17.97 & \\
\hline
\end{tabular}

Source: own calculation.

Table 2. The optimal values of VAT rates calculated on the basis of the model with the real government deficit and the structural government deficit as well as the real values of VAT rate

\begin{tabular}{|c|c|c|c|}
\hline Year & $\begin{array}{c}\text { The optimal VAT rate calculated } \\
\text { on the basis of the model } \\
\text { with the real government deficit }\end{array}$ & $\begin{array}{c}\text { The optimal VAT rate calculated } \\
\text { on the basis of the model with } \\
\text { the structural government deficit }\end{array}$ & Real VAT rate \\
\hline 2003 & 22.45 & 22.35 & 22 \\
\hline 2004 & 22.51 & 22.14 & 22 \\
\hline 2005 & 21.97 & 22.12 & 22 \\
\hline 2006 & 21.87 & 22.11 & 22 \\
\hline 2007 & 22.02 & 22.09 & 22 \\
\hline 2008 & 22.19 & 22.16 & 22 \\
\hline 2009 & 22.14 & 22.32 & 22 \\
\hline 2010 & 22.30 & 22.46 & 23 \\
\hline 2011 & 22.51 & 22.51 & 23 \\
\hline 2012 & 22.44 & 22.67 & 23 \\
\hline 2013 & 22.33 & 22.89 & 23 \\
\hline 2014 & 22.49 & 23.04 & 23 \\
\hline 2015 & 23.06 & 23.26 & \\
\hline
\end{tabular}

Source: own calculation. 
Thus we can observe the differences in optimal tax rates. The optimal basic PIT and VAT rates depend on the type of government deficit. In addition, taking into account the real government deficit and the structural government deficit, we can conclude that the assumed goals (price stability, GDP growth and the desired deficit level) would be achieved by a reduction of the basic PIT rate in the last period and by a slight VAT rate increase.

To analyze the values of tax rates that depend on the phase of the business cycle, in Table 3 we present the values of output gap - the variable that is treated as a business cycle variable. Table 3 also presents the phases of the business cycle that result from this analyses.

Table 3. The output gap and the phases of the business cycle

\begin{tabular}{|l|c|l|}
\hline Year & The output gap & $\begin{array}{l}\text { The phase of the } \\
\text { business cycle }\end{array}$ \\
\hline 2003 & 0.893 & Boom \\
\hline 2004 & 1.020 & Recession \\
\hline 2005 & 1.016 & Recession \\
\hline 2006 & 1.006 & Recession \\
\hline 2007 & 0.997 & Boom \\
\hline 2008 & 0.997 & Boom \\
\hline 2009 & 1.0004 & Recession \\
\hline 2010 & 1.004 & Recession \\
\hline 2011 & 0.996 & Boom \\
\hline 2012 & 0.999 & Boom \\
\hline 2013 & 1.002 & Recession \\
\hline 2014 & 1.021 & Recession \\
\hline 2015 & 1.035 & Recession \\
\hline 2016 & 0.872 & Boom \\
\hline
\end{tabular}

Source: own calculation.

The following table presents the optimal and real values of tax rates (PIT and VAT rates) with particular emphasis on the values of these rates in particular phases of the business cycle.

Tables 5 and 6 present the optimal values of PIT and VAT rates calculated on the basis of the models that take into account the different methodologies of deficit calculation. 
Table 4. The optimal values of PIT and VAT rates and the real values of these rates

\begin{tabular}{|c|l|c|c|c|c|}
\hline Year & $\begin{array}{c}\text { Phases of the business } \\
\text { cycle }\end{array}$ & $\begin{array}{c}\text { The optimal value } \\
\text { of PIT rate }\end{array}$ & $\begin{array}{c}\text { The real } \\
\text { PIT rate }\end{array}$ & $\begin{array}{c}\text { The optimal } \\
\text { value of VAT } \\
\text { rate }\end{array}$ & $\begin{array}{c}\text { The real } \\
\text { VAT rate }\end{array}$ \\
\hline 2003 & Boom & $\mathbf{1 7 . 7 9}$ & 19 & $\mathbf{2 2 . 4 5}$ & 22 \\
\hline 2004 & Recession & 18.34 & 19 & 22.51 & 22 \\
\hline 2005 & Recession & 18.70 & 19 & 21.97 & 22 \\
\hline 2006 & Recession & 18.91 & 19 & 21.87 & 22 \\
\hline 2007 & Boom & $\mathbf{1 8 . 9 9}$ & 19 & $\mathbf{2 2 . 0 2}$ & 22 \\
\hline 2008 & Boom & $\mathbf{1 8 . 7 7}$ & 19 & $\mathbf{2 2 . 1 9}$ & 22 \\
\hline 2009 & Recession & 18.62 & 18 & 22.14 & 22 \\
\hline 2010 & Recession & $\mathbf{1 8 . 4 8}$ & 18 & 22.30 & 22 \\
\hline 2011 & Boom & $\mathbf{1 8 . 2 6}$ & 18 & $\mathbf{2 2 . 4 4}$ & 23 \\
\hline 2012 & Boom & 18.01 & 18 & 22.33 & 23 \\
\hline 2013 & Recession & 17.82 & 18 & 22.49 & 23 \\
\hline 2014 & Recession & 17.10 & 18 & 23.06 & 23 \\
\hline 2015 & Recession & & & & \\
\hline
\end{tabular}

Source: own calculation.

Table 5. The optimal values of PIT rate calculated on the basis of the models with the government deficit and the general government deficit as well as real values of PIT rate

\begin{tabular}{|c|c|c|c|}
\hline Year & $\begin{array}{c}\text { The optimal values of PIT rate } \\
\text { calculated on the basis of the } \\
\text { model with the government } \\
\text { deficit }\end{array}$ & $\begin{array}{c}\text { The optimal values of PIT rate } \\
\text { calculated on the basis of the model } \\
\text { with the general government deficit }\end{array}$ & $\begin{array}{c}\text { The real } \\
\text { PIT rate }\end{array}$ \\
\hline 2003 & 17.79 & 17.82 & 19 \\
\hline 2004 & 18.34 & 18.52 & 19 \\
\hline 2005 & 18.70 & 18.59 & 19 \\
\hline 2006 & 18.91 & 19.02 & 19 \\
\hline 2007 & 18.99 & 19.22 & 19 \\
\hline 2008 & 18.77 & 18.65 & 19 \\
\hline 2009 & 18.62 & 18.20 & 18 \\
\hline 2010 & 18.41 & 18.25 & 18 \\
\hline 2011 & 18.48 & 18.47 & 18 \\
\hline 2012 & 18.26 & 18.08 & 18 \\
\hline 2013 & 18.01 & 17.91 & 18 \\
\hline 2014 & 17.82 & 17.81 & 18 \\
\hline 2015 & 17.10 & 17.25 & \\
\hline
\end{tabular}

Source: own calculation. 
The obtained results are presented in the Figure 3.

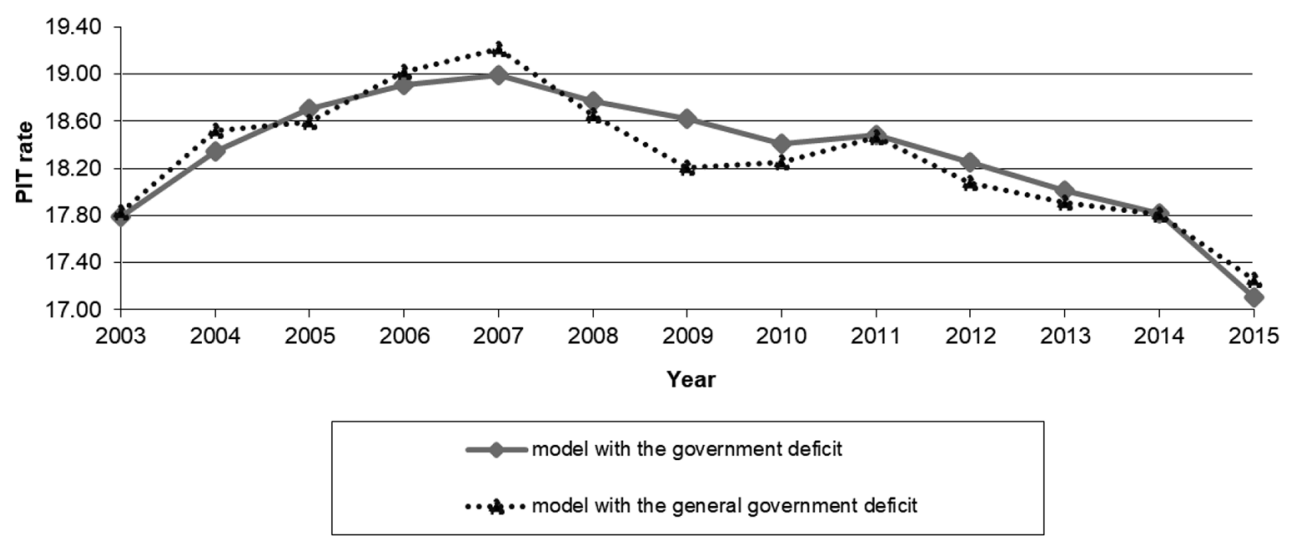

Fig. 3. The optimal values of PIT rate calculated on the basis of the models with the government deficit and the general government deficit

Source: own calculation.

Table 6. The optimal values of VAT rate calculated on the basis of the models with the government deficit and the general government deficit as well as the real values of VAT rate

\begin{tabular}{|c|c|c|c|}
\hline Year & $\begin{array}{c}\text { The optimal values of VAT rate } \\
\text { calculated on the basis of the model } \\
\text { with the government deficit }\end{array}$ & $\begin{array}{c}\text { The optimal values of VAT } \\
\text { rate calculated on the basis } \\
\text { of the model with the general } \\
\text { government deficit }\end{array}$ & $\begin{array}{c}\text { The real values } \\
\text { of VAT rate }\end{array}$ \\
\hline 2003 & 22.45 & 22.94 & 22 \\
\hline 2004 & 22.51 & 23.10 & 22 \\
\hline 2005 & 21.97 & 22.35 & 22 \\
\hline 2006 & 21.87 & 22.55 & 22 \\
\hline 2007 & 22.02 & 22.51 & 22 \\
\hline 2008 & 22.19 & 22.51 & 22 \\
\hline 2009 & 22.14 & 23.03 & 23 \\
\hline 2010 & 22.30 & 23.17 & 23 \\
\hline 2011 & 22.51 & 23.06 & 23 \\
\hline 2012 & 22.44 & 22.27 & 23 \\
\hline 2013 & 22.33 & 22.03 & 22.29 \\
\hline 2014 & 22.49 & 22.93 & 22 \\
\hline 2015 & 23.06 & & 22 \\
\hline
\end{tabular}

Source: own calculation. 
The optimal values of the basic PIT rate calculated on the basis of the models with the government deficit and the general government deficit are different. In addition, taking into account the various methodologies of the deficit calculation we can conclude that the PIT rate obtained on the basis of all considered models, should be reduced in the last period.

The obtained results are presented in the Figure 4.

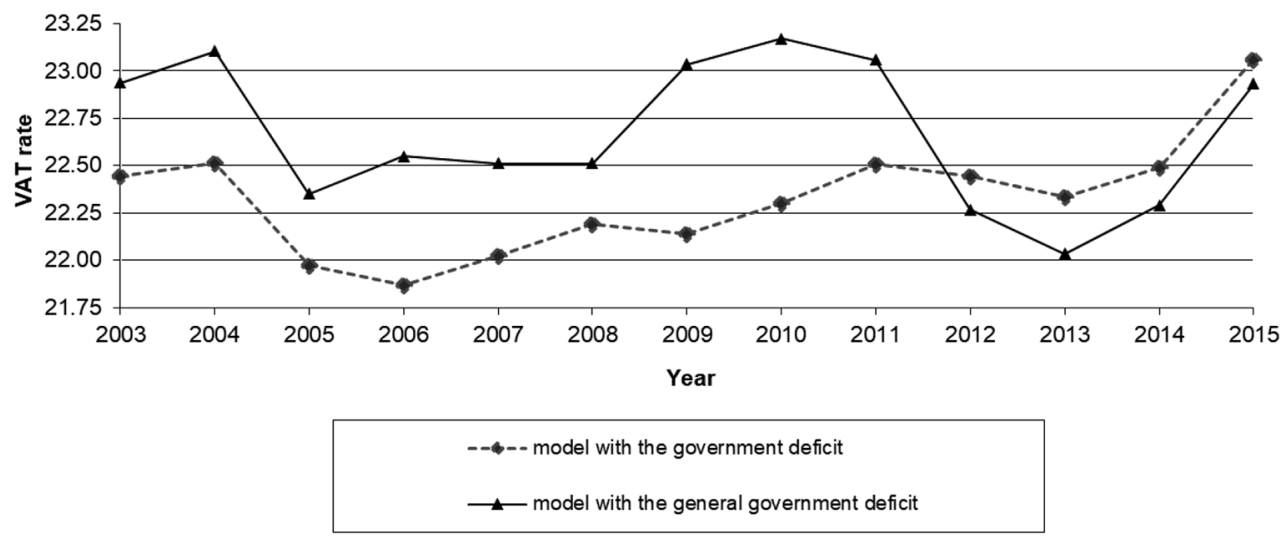

Fig. 4. The optimal values of VAT rate calculated on the basis of the models with the government deficit and the general government deficit

Source: own calculation.

We can notice the analogous conclusion for the basic VAT rate for the basic PIT rate. Therefore the optimal values of the basic VAT rate calculated on the basis of the model with the government deficit and the general government deficit model differs. The larger differences in the optimal values of the basic VAT rate are obtained on the basis of the model with the government deficit. In addition, only the government deficit indicated the need to increase the basic VAT rate in the recent period. The optimal values of the basic VAT rate calculated on the basis of model with the general government deficit indicate the possibility of a reduction of the basic VAT rate in the last period of the analyses based on the statistical data. In addition, the result obtained in the model with the general government deficit indicates the achievement of the assumed goals when the optimal values of the basic VAT rate are also lower than the real values of this VAT rate in other periods.

\section{Conclusion}

Since the economy can be perceived as a dynamic system with control, the use of a quadratic-linear tracking problem solution will help to develop the economy according to the desired path. The optimal values of the tax rates determined in 
the article as a solution of the quadratic-linear problem minimize the deviation of inflation, GDP and deficit from their desired values. Because one of the variables in the quadratic-linear problem is a deficit, we studied whether there is an impact of the type of the deficit and the methodology of estimation of the deficit on the values of the optimal tax rates. We took into account the basic PIT rate and the basic VAT rate in the analyses. On the basis of the research we verified positively the hypothesis that the type of the deficit has an impact on the tax rate.

Therefore when we make decisions about the optimal values of tax rates which allow to achieve the assumed goals - in the article the price stability and the desirable levels of GDP and deficit - we should take into account the type of deficit and the methodology of the calculation of the deficit.

We should note that in this article we made an ex-post analysis based on the available statistical data. When we know the forecasts of the state variables i.e. the inflation rate forecasts, the forecasts of the GDP growth rate and the forecasts of the deficit to GDP ratio, we will be able to determine the forecasts of the optimal values of the tax rates.

This article is a supplement to the analyses presented in the papers by other researchers. In this article we used the algorithm based on the control theory and based on the dynamic model taking into account the feedback rules and different types of government deficit in the fiscal decision making process. The aim of the article was also to draw fiscal decision-makers' attention to the influence of the type of deficit on the values of tax rate.

\section{Bibliography}

Benigno P., Woodford M., 2012, Linear-quadratic approximation of optimal policy problems, Journal of Economic Theory, 147(1), pp. 1-42.

Boiciuc I., 2015, The cyclical behavior of fiscal policy in Romania, Procedia Economics and Finance 32 , pp. 286-291.

Camelia M., 2014, Estimation and Analysis of the Structural Budget Deficit in Romania, International Journal of Academic Research in Economics and Management Sciences, vol. 3, no 4.

Ellison M., Optimal Linear Quadratic Control, Lecture notes in Recursive Methods for Macroeconomics, http://users.ox.ac.uk/ exet2581/recursive/lqg_mat.pdf.

Fantacone S., Garalova P. G., Milani C., 2015, Structural budget balance and fiscal policy: the limits of the European approach, Yildiz Social Science Review.

Ferrante A., Ntogramatzidis L., 2013, The generalised discrete algebraic Riccati equation in linear-quadratic optimal control, Automatica, 49(2), pp. 471-478.

Kendrick D., 1982, Stochastic control for economic models, Journal of Economic Dynamic and Control, 1(3), pp. 311-313.

Kendrick D., Amman H., 2011, A Taylor Rule for Fiscal Policy, Utrecht, Netherlands: Utrecht School of Economics, Tjalling C. Koopmans Research Institute, Discussion Paper Series.

Okafor S.O., Maduka O.D., Ike A.N., Uzoechina B.I., Ohachosim C.I. (September 2017), Tax-budget Deficit Relationships: Fiscalists' platform for deficit financing policy, Business and Management Studies, vol. 3, no 3. 
Przybylska-Mazur A., 2016, Application of selected dynamic models to the analysis of the impact balanced budget rule on the economy, The 10th Professor Aleksander Zelias International Conference on Modelling and Forecasting of Socio-Economic Phenomena, Conference Proceedings edited by Monika Papież and Sławomir Śmiech, Publishing House: Foundation of the Cracow University of Economics, pp. 139-148.

\section{RODZAJE DEFICYTU BUDŻETOWEGO W ASPEKCIE PODEJMOWANIA DECYZJI FISKALNYCH}

Streszczenie: Polityka fiskalna obejmuje decyzje rządu na temat wielkości podatków, które mają wpływ na wielkość deficytu budżetowego. Istnieją różne rodzaje deficytu budżetowego. Celem przeprowadzonych analiz jest zbadanie zależności między rodzajem deficytu a optymalnym poziomem stopy podatkowej. W artykule zweryfikowano hipotezę, że rodzaj rozważanego deficytu ma wpływ na wysokość stopy podatkowej. Do weryfikacji hipotezy wykorzystano reguły sprzężenia zwrotnego będące rozwiązaniem problemu kwadratowo-liniowego.

Słowa kluczowe: deficyt, stopa podatkowa, reguła sprzężenia zwrotnego, problem kwadratowo-liniowy. 